\title{
Testing Agro-Ecological Adaptation of Improved Herbaceous Forage Legumes in South-Kivu, D.R. Congo
}

\author{
M. M. D. Katunga',2, J. B. B. Muhigwa3 ${ }^{3}$ K. J. C. Kashala ${ }^{4}$, L. Ipungu', N. Nyongombe ${ }^{5}$, \\ B. L. Maass' ${ }^{6}$, M. Peters ${ }^{7}$ \\ ${ }^{1}$ Centre International d'Agriculture Tropicale (CIAT), Bukavu, D.R. Congo \\ ${ }^{2}$ Institut National pour l'Etude et la Recherche Agronomiques (INERA)-Mulungu, Bukavu, D.R. Congo \\ ${ }^{3}$ Officielle de Bukavu, Faculté des sciences, Bukavu, D.R. Congo \\ ${ }^{4}$ Université de Lubumbashi, Faculté de Médecine Vétérinaire, Lubumbashi, D.R. Congo \\ ${ }^{5}$ Université Pédagogique Nationale de Kinshasa, Kinshasa, D.R. Congo \\ ${ }^{6} \mathrm{CIAT}$, Nairobi, Kenya \\ ${ }^{7}$ CIAT, A.A. 6713, Cali, Colombia \\ Email: katungamusale@yahoo.fr, stylonya@gmail.com, jeanmuhigwa@yahoo.fr, jckkashala@hotmail.fr, \\ nyongombenathan@gmail.com, $\underline{\text { b.maass@cgiar.org, m.peters-ciat@cgiar.org }}$
}

Received 12 February 2014; revised 22 March 2014; accepted 16 April 2014

Copyright (C) 2014 by authors and Scientific Research Publishing Inc.

This work is licensed under the Creative Commons Attribution International License (CC BY).

http://creativecommons.org/licenses/by/4.0/

(c) (i) Open Access

\begin{abstract}
In tropical african countries where livestock is either reared in herds on natural grasslands or individuallly tethered to herds on natural or spontaneous vegetation, the productivity is low, especially during the dry season. Using improved forages could play an important role in both enhancing livestock production and improving soil fertility and preventing from soil erosion. Eleven herbaceous forage legumes previously tested in tropical South America and South Asia by CIAT were tested in South-Kivu, D. R. Congo. Across sites, Stylosanthes guianensis, Desmodium uncinatum, Centrosema molle and Canavalia brasiliensis had a highest yield, nowhere Vigna unguiculata adapted. Differencial plant adaptation occured, e.g. Clitoria ternatea being well adaptated only in the midlands with good soils, where the mean of dry mater leaf yield was higher. Farmer evaluation emphazied overall biomass production with preference in the highlands, farmers chose Desmodium uncinatum, Canavalia brasiliensis and Lablab purpureus 21603 and in the midlands Stylosanthes guianensis 11995 and Lablab purpureus 22759. Farmer evaluation confirmed the best yield fit herbaceous forage legumes.
\end{abstract}

\section{Keywords}

Herbaceous Forage Legumes; Adaptation; Tropical Africa 


\section{Introduction}

Agriculture in South-Kivu Province in D.R. Congo is still managed with crop integration [1] [2]. Demographic pressure on the land is highly due to unequal distribution. However, the environment enduring insecurity and poverty challenges hinders any new research initiative [3]. There are low crop productions due to poor soil management, small homelands of farmers, lack of extension services, leading to alarming nutritional status [4]. Livestock productivity is low, especially during the dry season. The forage crops are not exercised again to feed small animals [5] whereas improved forages could play an important role in both enhancing livestock production and improving soil fertility also preventing from soil erosion. However, several studies have been conducted on herbaceous fodders in the tropical region and especially in the Southeast and central Asia, in Australia and in Africa [6]-[8]. They led to selection of species and accessions notably on the basis of agronomic tests and participatory evaluation by farmers. Among most cosmopolitan we keep these effective species notably Stylosanthes spp., Lablab spp., Andropogon spp., Brachiaria spp. etc.

In Zimbabwe, the biomass production was very low for most legumes across all sites and the promising accessions were Chamaecrista rotundifolia cv. 93094, C. rotundifolia cv. Wynn, C. pilosa, Aeschynomene villosa $c v$. Reid and A. villosa cv. Kretschmer [9]. The biomass and maximum grain yield are a diversity in growth characteristics that suggests potential for lablab to be a multi-purpose crop for use in the smallholder systems of South Africa [10]. The annual legumes, lablab and Centrosema pascuorum Q 10050 were the highest yielding in the first year at both sites and Macroptilium bracteatum cvv. Juanita and Cadarga have persisted at both sites, producing some forage in the third season [11]. The flowering of Centrosema molle is rare [12].

This study aimed at testing adaptation improved herbaceous forage legumes selected in Tropical America by Centro International de Agricultura Tropical (CIAT) agronomic performance and farmer participatory evaluation in using various agroecological zones in South-Kivu, to draw a model for similar areas.

\section{Material and Methods}

\subsection{Agronomic Trial}

Eleven herbaceous legume species and accessions pre-selected from previous evaluation under similar ecological conditions in tropical America and South-Est Asia were tested. This research included Canavalia brasiliensis CIAT 17009, Centrosema molle CIAT 15160, Clitoria ternatea CIAT 20692, Lablab purpureus CIAT (21603, 22759), Macroptilium atropurpureum cv. Siratro, Sylosanthes guianensis CIAT 11995, Vigna unguiculata CIAT (IT95K52-34, IT97K132-1, IT98K1069-6) and Desmodium uncinatum cv. Silverleaf (ILRI 6763) as a control. Researcher-managed, four plots for agronomic and farmers' evaluation within the agro-ecological conditions in Sud-Kivu, D. R. Congo, Nov 2009-Feb 2011. The Table 1 shows the location of the experimental sites.

Every plot measured $3 \mathrm{~m} \mathrm{x} 3 \mathrm{~m}$, and installed in randomized blocs. The seedlings were planted in the line with a spacing of $0.25 \mathrm{~m}$. First cutting was done after flowering started for $50 \%$ per individual specie or accession according to site and plant physiology. Diseases and pests were observed according the scale of Toledo [13]. Plants were cut every 2 months for agronomic evaluation. Cuttings were stopped at the level of the fourth cut because more of the $50 \%$ of fodders had disappeared following the pressure of cuts in all sites.

Table 1. Location and soil fertility of the 4 sites.

\begin{tabular}{|c|c|c|c|c|c|c|c|c|}
\hline \multirow[t]{2}{*}{ Site } & \multicolumn{4}{|c|}{ Soil fertility } & \multirow{2}{*}{\multicolumn{2}{|c|}{ Latitude }} & \multirow[t]{2}{*}{ Longitude } & \multirow[t]{2}{*}{$\begin{array}{c}\text { Elevation } \\
\text { (m asl) }\end{array}$} \\
\hline & $\mathrm{pH}$ & K & $\mathrm{P}(\mathrm{O})$ & C.E.C & & & & \\
\hline & Water & EXK1000G & ppm & meq/100g & $\%$ & & & \\
\hline Mulungu & 5.15 & 0.36 & 3 & 20 & 0.38 & $2.19^{\circ} \mathrm{S}$ & $28.47^{\circ} \mathrm{E}$ & 1700 \\
\hline Nyangezi & 3.94 & 0.18 & 3 & 3 & 0.15 & $2.88^{\circ} \mathrm{S}$ & $27.03^{\circ} \mathrm{E}$ & 1580 \\
\hline Kamanyola & 6.42 & 0.35 & 2 & 34 & 0.25 & $2.01^{\circ} \mathrm{S}$ & $29.01^{\circ} \mathrm{E}$ & 900 \\
\hline Tubimbi & 4.29 & 0.22 & 2 & 3 & 0.19 & $2.79^{\circ} \mathrm{S}$ & $23.59^{\circ} \mathrm{E}$ & 1100 \\
\hline
\end{tabular}




\subsection{Data Collection}

Days to 50\% flowering per individual specie or accession ranged. Leaves were separated with stems before weighing with balance SF-400 (1 g $\pm 10 \mathrm{~kg})$. The mean of dry leaf yield (MDLY) in the results, concern the total leaves and stems for some forages. A homogeneous sample respectively of leaves and stems of $300 \mathrm{~g}$ was taken at every harvest and kept during 3 months until a constant weight in a sun drier which reached $40^{\circ} \mathrm{C}-45^{\circ} \mathrm{C}$ in bright time. Fresh leaf and stem yield (FLY) $\mathrm{kg} \mathrm{ha}^{-1}=\mathrm{FLY}(\mathrm{g}) \times \mathrm{DM}(\%) / \mathrm{Su}\left(\mathrm{m}^{2}\right) \times 10$, dry mater in $\mathrm{kg} / \mathrm{ha}$ $(\mathrm{DLY})=\left[\mathrm{kg} \mathrm{ha}^{-1}(\mathrm{FLY})\right] \times[\mathrm{ADM}(\%)] / 100$ [7]. Samples of leaves were analyzed at International Livestock Research Institute at Addis Ababa on near infrared reflectance spectroscopy for nutrient contents (DM, OM, CP, NDF, ADF, ADL and TIVOMD). Farmers evaluation was done during rainy and dry season at all 4 sites with 5 women and 5 men per location and season indicating preferences according to own criteria; farmers' selection criteria gathered, plots selected by dropping a white paper and data presented as ranks of preference at location. After the choice of forages, the two teams got together to discuss and reach a gender consensus [14] [15].

\subsection{Data Analyses}

To harmonize the cutting number, a mean was done for all forages. Descriptive statistics were done and differences of MDLY were established by ANOVA, graphs in STATVIEW software and Correspondence analysis in Past Software.

\section{Results}

\subsection{Agronomic Evaluation}

\subsubsection{Diseases and Pests}

The Table 2 indicates the ranks of diseases and pests.

- In highlands with rich soils (Mulungu): C. brasiliensis 17009 for diseases with regard to pests, it was D. uncinatum and S. guianensis 11995.

- In highlands with poor soils (Nyangezi): D. uncinatum and S. guianensis 11995 for diseases and for pests C. brasiliensis 17009, C. molle 15160, D. uncinatum, L. purpureus 22759 and S. guianensis 11995.

- In midlands with rich soils (Kamanyola) all species and accessions had score 1, except Cowpeas, C. brasiliensis and C. molle.

- In midlands with poor soils (Tubimbi): C. brasiliensis 17009, C. molle 15160 and S. guianensis 11995 for diseases and C. brasiliensis 17009, C. molle 15160, S. guianensis 11995 and V. unguiculata 1069-6 for pests.

The best fodders in highlands were C. brasiliensis and D. uncinatum, overall S. guianensis, in midlands with poor soils $S$. guianensis and C. molle.

NB: In Mulungu, the three accessions of Vigna unguiculata did not grow, equal in Tubimbi for D. uncinatum and C. ternatea.

Table 2. Ranks of herbaceous forage legumes to diseases and pests per site (means, $n=11$ ).

\begin{tabular}{cccccccccc}
\hline \multirow{2}{*}{ Forage herbaceous legumes } & \multicolumn{2}{c}{ Mulungu } & \multicolumn{2}{c}{ Nyangezi } & \multicolumn{2}{c}{ Kamanyola } & \multicolumn{2}{c}{ Tubimbi } \\
\cline { 2 - 8 } C. brasiliensis 17009 & Diseases & Pests & Diseases & Pests & Diseases & Pests & Diseases & Pests \\
C. molle 15160 & 1 & 2 & 2 & 2 & 2 & 2 & 1 & 1 \\
C. ternatea 20692 & 2 & 2 & 2 & 2 & 1 & 2 & 1 & 1 \\
D. uncinatum 6765 & 3 & 2 & 3 & 2 & 1 & 1 & n.m & n.m \\
L. purpureus 21603 & 2 & 1 & 1 & 2 & 1 & 1 & n.m & n.m \\
L. purpureus 22759 & 2 & 2 & 2 & 2 & 1 & 1 & 2 & 2 \\
M. atropurpureum var. Siratro & 2 & 2 & 2 & 2 & 1 & 1 & 2 & 2 \\
S. guianensis 11995 & 2 & 2 & 2 & 2 & 1 & 1 & 2 & 2 \\
V. unguiculata 52-34 & 2 & 1 & 1 & 1 & 1 & 1 & 1 & 1 \\
V. unguiculata 1069-6 & n.m & n.m & 3 & 2 & 3 & 2 & 2 & 2 \\
V. unguiculata 131-2 & n.m & n.m & n.m & 3 & 3 & 3 & 2 & 2 & 1 \\
\hline
\end{tabular}

${ }^{*}$ n,m.: whtat is not mentioned. Fodders less attacked by diseases and pests with score 1 were. 


\subsubsection{Flowering}

The Figure 1 shows the duration of flowering of herbaceous forage legumes.

According to various durations of flowering, the intervals suggested here are: fast flowering 67-105 days, moderate duration until flowering 105 to 211 days, and slow flowering 211-278 days.

Fodders fast flowering in the highlands with rich soils (Mulungu) are; L. purpureus 21603, L. purpureus 22759, S. guianensis 11995, V. unguiculata 52-34. In the highlands with poor soils (Nyangezi) it was S. guianensis 11995, V. unguiculata 52-34, V. unguiculata 131-2, V. unguiculata 1069-6, L. purpureus 22759 and L. purpureus 21603 and in the midlands with rich soils are in Kamanyola C. ternatea, L. purpureus 21603, V. unguiculata 131-2, M. atropurpureum and S. guianensis 11995 and in the midlands with poor soils in Tubimbi are V. unguiculata 1069-6 and V.unguiculata 131-2.

- Fodders with moderate flowering: in Mulungu C. ternatea, D. uncinatum, M. atropurpureum, V. unguiculata 131-2 and V. unguiculata 1069-6, in Nyangezi C. brasiliensis, C. ternatea, D. uncinatum, M. atropurpureum, in Kamanyola, C. brasiliensis, C. molle, D. uncinatum, L. purpureus 22759, V. unguiculata 1069-6 and V. unguiculata 52-34 in Tubimbi, C. brasiliensis, L. purpureus 22759, L. purpureus 21603, M. atropurpureum, S. guianensis 11995 and $V$. unguiculata 52-34.

- Fodders with slow flowering: in Mulungu C. brasiliensis, C. molle,; in Nyangezi C. molle and Tubimbi C. molle.

\subsubsection{Nutrient Values}

The Table 3 shows the nutritive values of the herbaceous forage legumes.

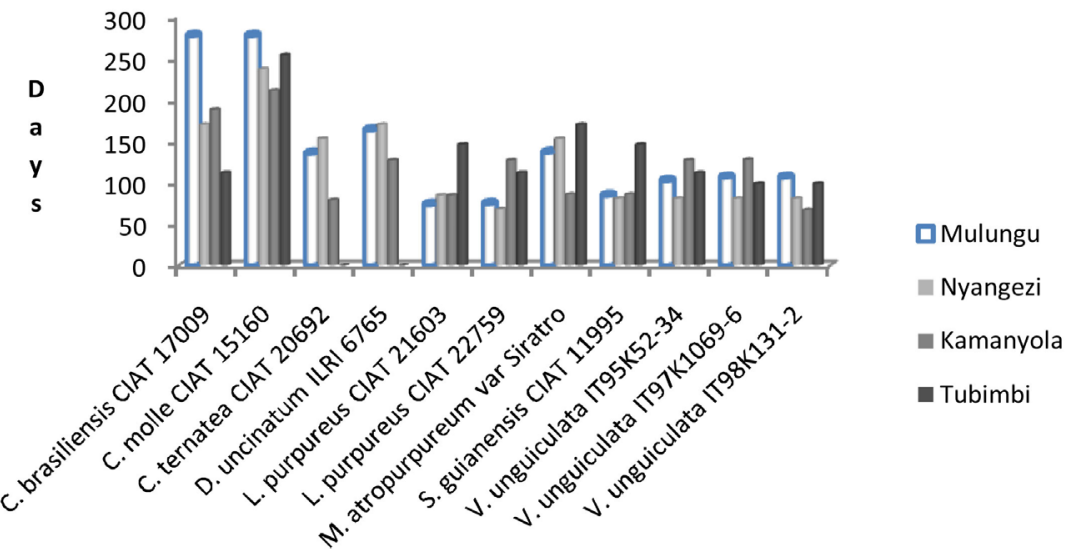

Forage herbaceous legumes

Figure 1. Duration (days) until for the herbaceous fodder (means).

Table 3. Nutrient contents (\%) of herbaceous forage legumes (overall means).

\begin{tabular}{cccccccc}
\hline Forage herbaceous legumes & DM $^{*}$ & OM & CP & NDF & ADF & ADL & TIVOMD \\
\hline C. brasiliensis 17009 & 25.2 & 90.5 & 27.3 & 36.7 & 28.1 & 5.5 & 60.6 \\
C. molle 15160 & 23.0 & 68.5 & 11.4 & 36.1 & 27.6 & 5.7 & 41.9 \\
C. ternatea 20693 & 26.7 & 91.1 & 21.2 & 45.6 & 30.7 & 7.2 & 60.0 \\
D. uncinatum 6765 & 28.5 & 92.4 & 21.3 & 49.3 & 32.4 & 8.8 & 56.1 \\
L. purpureus 21603 & 18.2 & 68.3 & 16.8 & 37.3 & 25.7 & 5.4 & 44.1 \\
L. purpureus 22759 & 19.5 & 68.5 & 17.1 & 38.7 & 23.7 & 5.4 & 44.4 \\
M. atropurpureum var. Siratro & 21.0 & 68.4 & 16.3 & 35.7 & 27.4 & 5.8 & 45.1 \\
S. guianensis 11995 & 19.5 & 67.2 & 15.2 & 38.3 & 29.2 & 6.6 & 43.6 \\
V. unguiculata 1069-6 & 32.8 & 90.9 & 24.9 & 50.5 & 32.5 & 7.6 & 57.9 \\
V. unguiculata 131-2 & 22.5 & 68.4 & 18.1 & 35.7 & 25.0 & 5.4 & 44.1 \\
V. unguiculata 52-34 & 21.6 & 68.2 & 18.4 & 36.4 & 25.4 & 5.7 & 43.3 \\
\hline
\end{tabular}

${ }^{*} \mathrm{DM}=$ Dry mater. $\mathrm{OM}=$ Organic matter, $\mathrm{Cp}=$ Crude proteins, NDF = Neutral Detergent Fiber. TIVOMD = True In Vitro Organic Mater Digestibility. 
The nutritive values of various forage legumes are very good according the crude proteins $(11.4 \%-27.3 \%)$, fibers and digestibility.

\subsubsection{Forage Production}

According to site ecology and forage physiology, the cuttings were done as follow; see Table 4 and Figures 2-4.

Species with the maximum number of cuts in the highlands were S. guianenses, M. atropurpureum, L. purpureus (22759 and 21603) and in the midlands, S. guianensis. The moderate number of cuts was observed in highlands on $D$. uncinatum and in midlands $C$. brasiliensis and $C$. molle. These numbers of cuts depend on more the elevation and not the quality of soils in the sites. The specie that kept the maximum of cuts in all sites is $S$. guianensis.

There were significant differences in the MDLY $(\mathrm{kg} / \mathrm{ha})$ of forage in the sites $(\mathrm{P}<0.5)$ respectively in Mulungu, Nyangezi and Tubimbi except in Kamanyola without significant difference $(\mathrm{P}>0.5)$, see Figure 2 . The best forages in terms of yield were; in Mulungu D. uncinatum, L. purpureus 21603, S. guianensis, in Nyangezi C. brasiliensis, D. uncinatum, S. guianensis, in Kamanyola C. molle, C. ternatea, M. atropurpureum, S. guianensis, L. purpureus 22759 and in Tubimbi S. guianensis and C. molle.

Table 4. Cuttings per specie or accession of herbaceous forage legumes (number).

\begin{tabular}{|c|c|c|c|c|}
\hline Forages & Mulungu & Nyangezi & Kamanyola & Tubimbi \\
\hline C. brasiliensis 17009 & 1 & 3 & 2 & 3 \\
\hline C. molle 15160 & 1 & 2 & 2 & 3 \\
\hline C. ternatea 20692 & 4 & 1 & 3 & 0 \\
\hline D. uncinatum 6765 & 3 & 3 & 4 & 0 \\
\hline L. purpureum 21603 & 4 & 3 & 1 & 1 \\
\hline L. purpureum 22759 & 4 & 4 & 1 & 1 \\
\hline M. atropurpureum var. Siratro & 4 & 4 & 3 & 1 \\
\hline S. guianensis 11995 & 4 & 4 & 4 & 4 \\
\hline V. unguiculata 1069-6 & 0 & 1 & 1 & 1 \\
\hline V. unguiculata 131-2 & 0 & 1 & 2 & 1 \\
\hline V. unguiculata 52-34 & 0 & 1 & 1 & 1 \\
\hline
\end{tabular}

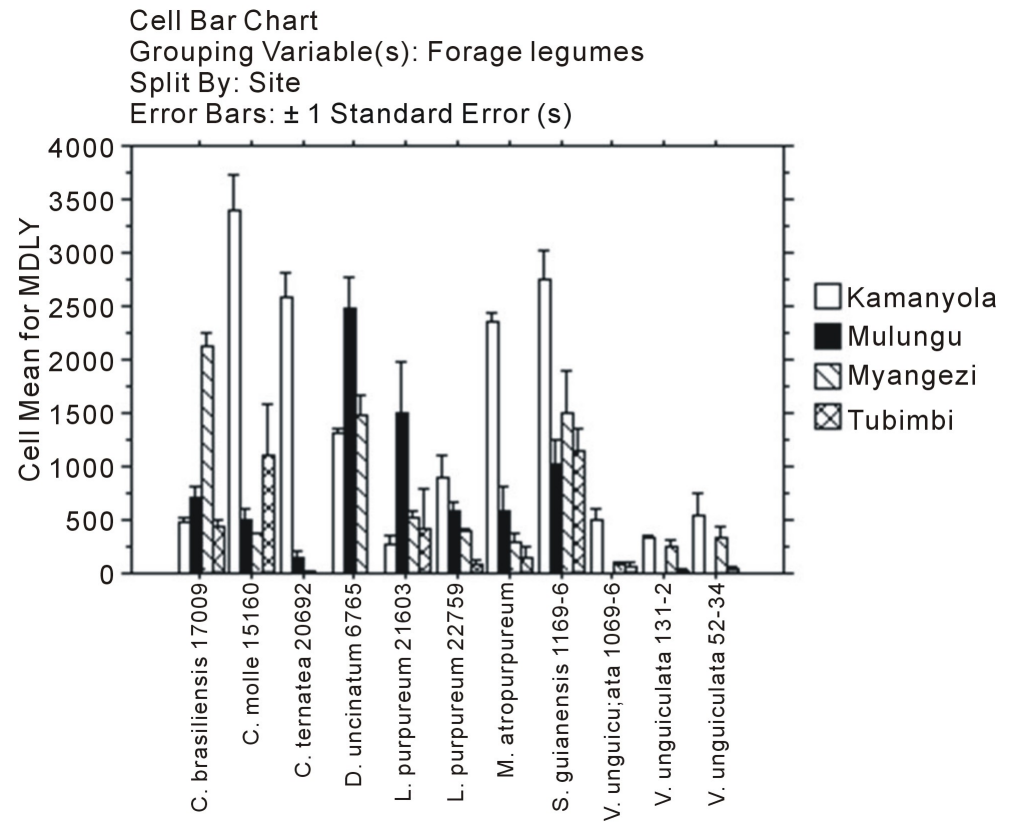

Figure 2. MDLY (kg/ha) of forage legumes per site. 


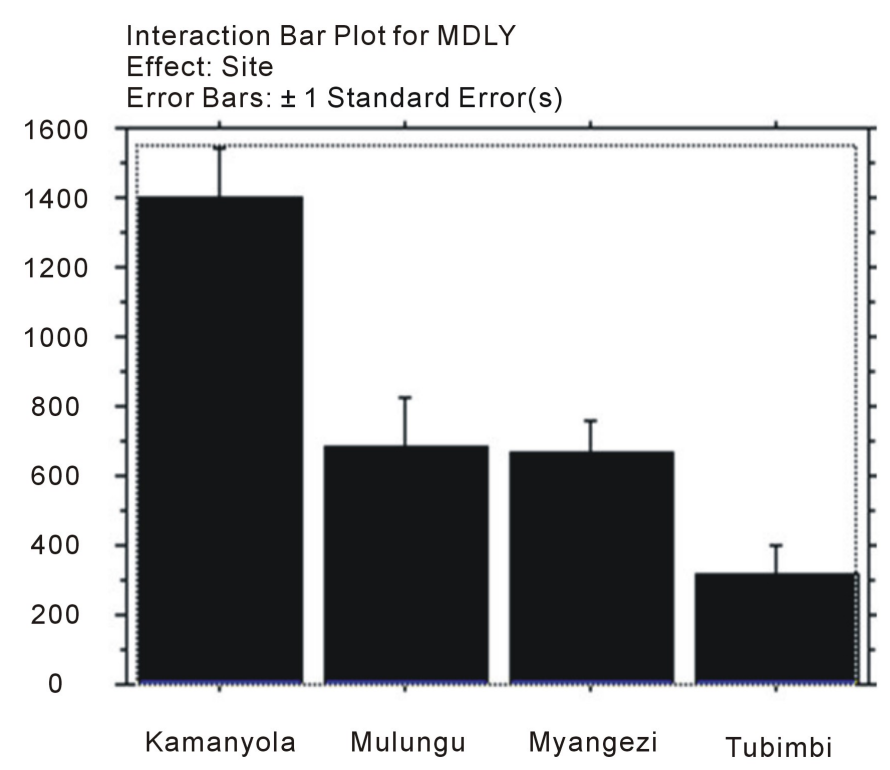

Figure 3. MDLY (kg/ha) of herbaceous forage legumes.

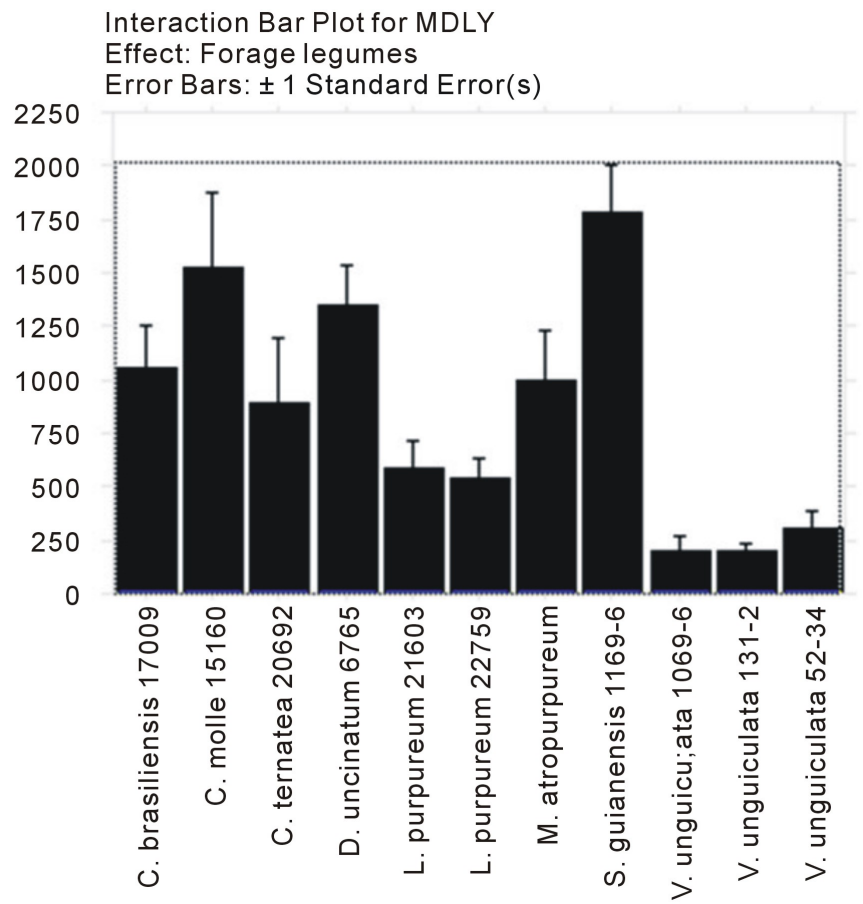

Figure 4. Overall MDLY (kg/ha) of herbaceous forage legumes per site.

There were no significant differences between sites $(\mathrm{P}>0.5)$, see Figure 3 and forages $(\mathbf{P}>\mathbf{0 . 5})$, see Figure 4. The overall highest performance (MDLY) was achieved in midlands with rich soils following by highlands with rich soils, highlands with poor soils and midlands with poor soils, the MDFY where fertility dependant. Only S. guianensis, $C$. molle and $D$. uncinatum were well adapted across all four locations, regard less fertility and elevation, $C$. ternatea adapted only in Kamanyola with good soils and high MDLY and different from the 3 other sites. But, C. brasiliensis and C. molle took time to establish well, e.g. biomass produced in first cut was low but later increased, V. unguiculata had a low adaptation and high capacity disease susceptibility, with only one cut. 


\subsection{Farmer's Participatory Evaluation}

The Table 5 and Figure 5 indicate the ranks of farmer's criteria.

Uneven ranking of drought tolerance demonstrated how important the timing of farmer evaluation was. They emphasized overall biomass production with preference in rainy season for C. brasiliensis and S. guianensis ahead of L. purpureus 22795 and L. purpureus 21603. During the dry season, S. guianensis is the first choice followed by C. brasiliensis, Lablab purpureus 21603 and M. atropurpureum, see the Figure 5.

The forages most chosen in dry and rainy seasons were constant for S. guianensis and C. brasiliensis followed by Lablab purpureus (21603, 22759).

The Figure 6 shows the farmer's choice of herbaceous forage legumes according the seasons.

(Eigen value of the two first axes reached $54.1 \%$, they fit well for analysis. The qualitative variables were the choice of farmers; MulRs = Mulungu in rainy season, NyaRs = Nyangezi in rainy season, KalRs = Kamanyola in rainy season, TubRs = Tubimbi in rainy season, MulDs = Mulungu in dry season, NyaDs = Nyangezi in dry season, KalDs = Kamanyola in dry season, TubDs = Tubimbi in dry season, see the Figure 6).

Choice of D. uncinatum, C. brasiliensis and L. purpureus 21603 were more obvious in Mulungu, Nyangezi in the rainy season and Mulungu in the dry season. On the other side, S. guianensis 11995 was chosen in Tubimbimostly in the rainy season, in Kamanyola and Tubimbi mainly in dry season, less L. purpureus 22759 and $V$. unguiculata 131-2 in Nyangezi in the dry season and in Kamanyola in the rainy season. On the other side, $S$.

\section{Table 5. Farmers criteria mentioned per season (rounded means).}

\begin{tabular}{ccc}
\hline Selection criteria identified by farmers & Dry season (Rank) n-21 women, 26 men & Rainy season (Rank) n-26 women, 14 men \\
\hline High biomass production & 1 & 1 \\
Dry season tolerance & 2 & $(6)^{*}$ \\
High nutritive value & 3 & 2 \\
Well accepted palatable & 4 & 3 \\
Disease resistant & 5 & $(8)^{*}$ \\
Improves soils fertility & $(9)^{*}$ & 4 \\
Serves for erosion control & n.m & 5 \\
Promotes high milk production & $(6)^{*}$ & n.m \\
\hline
\end{tabular}

${ }^{*}$ mentioned, but not among the top five; n.m.: not mentioned.

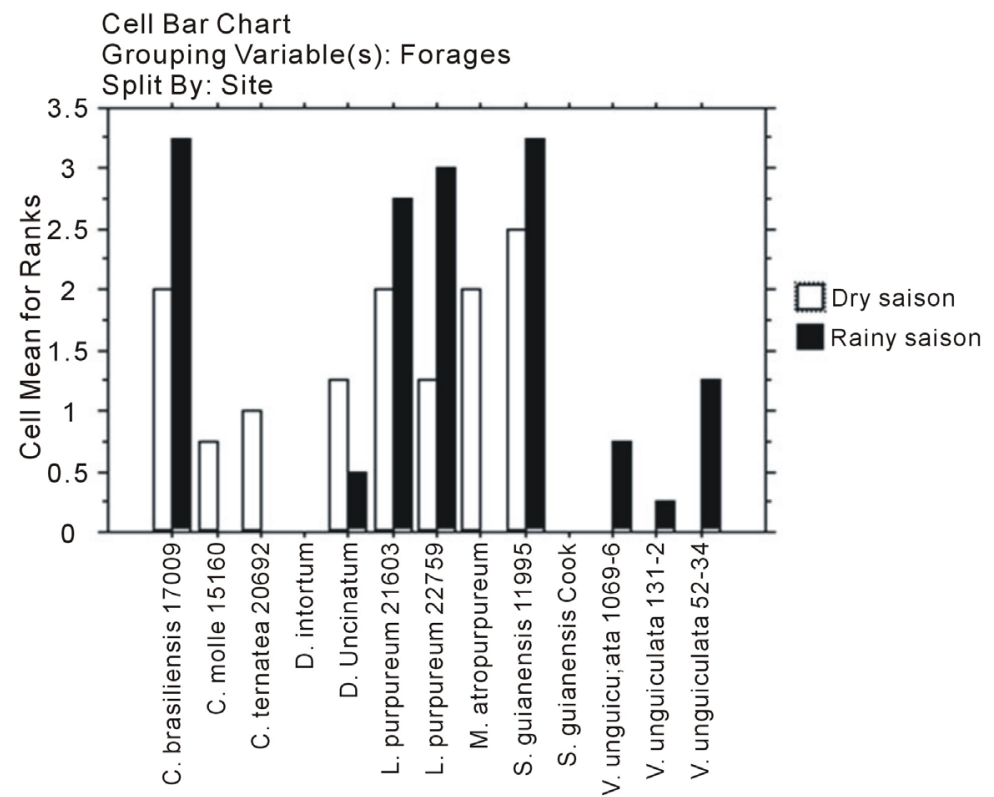

Figure 5. Rank of forages according to farmer's choice. 


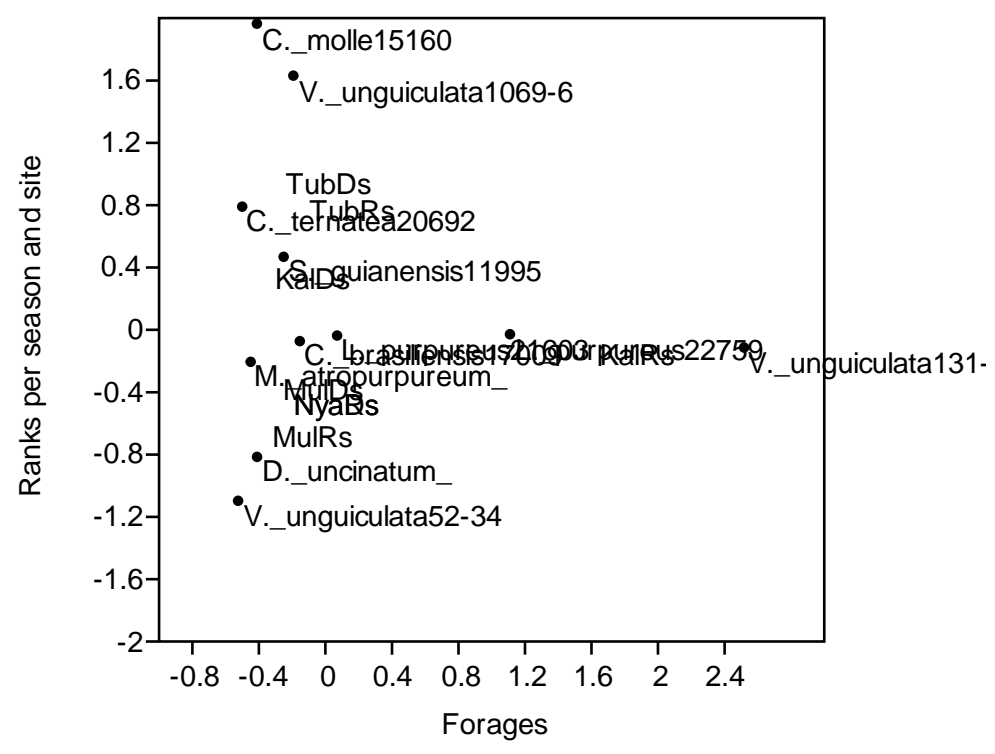

Figure 6. Correspondence analysis for forage legumes choice.

guianensis 11995 was chosen in Tubimbi mostly in the rainy season, in Kamanyola and Tubimbi mainly in dry season, less L. purpureus 22759 and V. unguiculata 131-2 in Nyangezi during the dry season and in Kamanyola in the rainy season.

\section{Discussion}

Regarding the production of leaf biomass S. guianensis, this forage was better with the production that was situated in every site. In Kamanyola it was higher than the 3 other sites. But it is lower than the one of the region of the Bourgou in Benin [16] and in the Queensland [11]. In Rwanda, the production of S. guianensis [17] was slightly high has the one of the South-Kivu. The range of his $\mathrm{pH}$ is 4.0 - 8.3 [6]. The production of M. atropurpureum was far lower than the one gotten to Broad Creek [11]. Besides, M. atropurpureum var Siratro produced less in Zimbabwe [9] than in South-Kivu while elsewhere in the same country the forage produced more [18] than here. In Mulungu L. purpureus 21603 adapted well here and in Tubimbi what goes in the margin of production in South Africa [10]. In Broad Creek, L. purpureus produced more [11] than in South-Kivu. The better yield of $D$. uncinatum was also observed at: Mulungu, Nyangezi and Kamanyola but it did not grow in Tubimbi. This production of $D$. uncinatum was higher than the one observed in Zimbabwe [11]. At last, C. ternatea was among the best fodders in Kamanyola in the midlands with the good soils whereas in of the all other sites, it did not fit. Accessions of $V$. unguiculata did not adapt at any site due to diseases susceptibility and plant loss after cuttings. Several authors show that aphides attack Vigna spp. and Lablab purpureus [19]-[21]. Criteria's of selection and choices of fodders by farmers are generally identical with agronomic results. This observation has also been made here in South-Kivu [22] who worked on cassava-legumes intercropping system. There are some factors that can influence the adoption positively, notably the approach in extension services, the age of farmers, the climatic constraints [23] and the integration of socio economic issues in fodder promotion [18].

\section{Conclusion}

Among the 11 herbaceous forage legumes tested in 4 diversified ecological sites of Sud-Kivu, D. R. Congo, $S$. guianensis, C. molle, $C$. brasiliensis and $D$. uncinatum were the best adapted as assessed in terms of diseases and pests, mean dry matter leaf yield and drought-tolerance. Only in Kamanyola with good soils, C. ternatea performed very well. The overall MDLY depended on soil fertility. Diseases and pests impacts were more important in Kamanyola where seed production is recommended. Further surveys could identify various pests and diseases and could determine their severity. Farmer evaluation chose Canavalia brasiliensis and Stylosanthes guianensis, Lablab purpureus 21603 and Macroptilium atropurpureum, in most cases they confirmed the yield fittest forage legumes. Plant health evaluated because diseased plants existed. Further on-farm experimentation 
suggested that food-feed crops prefer vulnerable environments to more fertile areas.

\section{References}

[1] Cox, T.P. (2012) Farming in the Battlefield: The Meanings of War, Cattle and Soil in South Kivu, Democratic Republic of the Congo. Disasters, 36, 233-248. http://dx.doi.org/10.1111/j.1467-7717.2011.01257.x

[2] Ouma, E., Birachi, E., Pypers, P., Van Lauwe, B., Ekesa, B., et al. (2011) CIALCA Baselines Survey. CIALCA Technical Report 17, CIAT. IITA. Bioversity International, Nairobi, Kenya and Ibandan, Nigeria. www.cialca.org/files/files/cialca\%20baselines\%20survey\%20report_print.pdf

[3] Maass, B.L., Katunga, M.M.D., Chiuri, W.L., Gassner, A. and Peters, M. (2012) Challenges and Opportunities for Smallholder Livestock Production in Post-Conflict South Kivu, Eastern DR Congo. Tropical Animal Health and Production, 44, 1221-1232.

[4] Katunga, M.M. (2004) Animal-Agriculture System in Bushi and Buhavu, Eastern Part of D. R. Congo RDC; Challenge against Malnutrition. CERPRU ISDR Bukavu R.D. Congo, 89.

[5] Katunga, M.M.D. (2013) Adaptation and Participatory Forage Leguminous in a System of Raising Integrating the Rabbit and the Guinea Pig to the South-Kivu, R. D. Congo. Ph. D. Thesis, University of Lubumbashi, Lubumbashi.

[6] Cook, B., Pengelly, B., Brown, S., Donnelly, J., Eagles, D., Franco, A., Hanson, J., Mullen, B., Partridge, I., Michael, P. and Schultze-Kraft, R. (2005) CIAT Tropical Forages, Index Forages. www.tropicalforages.info

[7] Network of Researches in Feeding of Livestock in West and Centrale Africa (1998) Report of Synthesis, Rabaoc, CIRAD-EMVT. Report No 98-044, CIAT, ILRI et CORAF, 88.

[8] Whitbread, M. and Pengally, B.C. (2004) Tropical Legumes for Sustainable Farming System in Southern Africa and Australia. Australia Center for International Agriculture Research Canberra, 180.

[9] Mugabe, P.H., Majee, D., Poshiwa, X., Chigariro, B., Ndlovu, B., Washayanyika, F. and Mukombe, N. (2004) Evaluation of Herbaceous Fodder Legumes Introduced into Communally Managed Rangelands in Zimbabwe. In: Whitbread, A.M. and Pengelly, B.C., Eds., Tropical Legumes for Sustainable Farming Systems in Southern Africa and Australia, ACIAR Proceedings No. 115, 51-57.

[10] Ayisi, K.K., Bopape, M.P. and Pengelly, B.C. (2004) Assessment of the Variation in Growth and Yield of Diverse Lablab (Lablab purpureus) Germplasm in Limpopo Province, South Africa. In: Whitbread, A.M. and Pengelly, B.C., Eds., Tropical Legumes for Sustainable Farming Systems in Southern Africa and Australia, ACIAR Proceedings No. 115, 44-50.

[11] Clem, R.L. and Cook, B.G. (2004) Identification and Development of Fodder Species for Long-Term Pasture Leys for the Southern Speargrass Region of Queensland. In: Whitbread, A.M. and Pengelly, B.C., Eds., Tropical Legumes for Sustainable Farming Systems in Southern Africa and Australia, ACIAR Proceedings No. 115, 64-72.

[12] Fantz, P.R. (2004) Distribution of Centrosema (DC). Benth. (Leguminosae: Phaseoleae: Clitoriinae) for the Flora Mesoamericana Project. Vulpia, 3, 99-139.

[13] Toledo, J.M. (1982) Manual para la Evaluación Agronómica. Red Internacional de Evaluación de Pastos Tropicales. CIAT, Cali, 170.

[14] Stür, W.W., Horne, P.M., Gabunada, F.A., Phengsavanh Jr., P. and Kerridge, P.C. (2002) Fodder Options for Smallholder Crop-Animal Systems in Southeast Asia: Working with Farmers to Find Solutions. Agricultural Systems, 71, 75-98. http://dx.doi.org/10.1016/S0308-521X(01)00037-3

[15] Tarawali, S.A., Tarawali, G., Larbi, A. and Hanson, J. (1995) Methods for the Evaluation of Fodder Legumes Grasses and Fodder Trees for Use as Livestock Feed International. Livestock Research Institute Nairobi, Kenya, ILRI, Fodders Evaluation.

[16] Adjolohoun, S., Bindelle, J., Adandédjan, C. and Buldgen, A. (2008) Some Suitable Grasses and Legumes for Ley Pastures in Sudanian Africa: The Case of the Borgou Region in Benin. Biotechnology, Agronomy, Society and Environment, 12, 405-419.

[17] Barhahenda, M., Shem, M.N., Kanuya, N.L., Ntababeza, I., Gasana, J., Uwimana, G., Unumezero, O. and Uwumukiza, D. (2007) Yield Potential of Grass-Legume Pastures under Different Management Conditions. Isar Rwanda Research of Animal Sciences, 1, 59-61.

[18] Pengelly, B.C., Whitbread, A., Mazaiwana, P.R. and Mukombe, N. (2004) Tropical Fodder Research for the FutureBetter Use of Research Resources to Deliver Adoption and Benefits to Farmers Tropical. In: Whitbread, A.M. and Pengelly, B.C., Eds., Tropical Legumes for Sustainable Farming Systems in Southern Africa and Australia, ACIAR Proceedings No. 115, 27-37.

[19] Nyoka, R., Chikumba, N., Chakoma, I., Mazaiwana, P., Mukombe, N. and Magwenzi, N. (2004) Evaluation and Screening of Fodder Legumes for Sustainable Integration into Crop-Livestock Farming Systems of Wedza District. In: Whit- 
bread, A.M. and Pengelly, B.C., Eds., Tropical Legumes for Sustainable Farming Systems in Southern Africa and Australia, ACIAR Proceedings No. 115, 58-63.

[20] Singh, B.B. and Tarawali, S.A. (1997) Cowpea and Its Improvement: Key to Sustainable Mixed Crop/Livestock Farming Systems in West Africa. International Institute of Tropical Agriculture, IITA Kano Station, PMB 3112, Kano, ILRI International Livestock Research Institute, PMB 5320, Ibadan. http://www.ilri.org/InfoServ/Webpub/Fulldocs/Cropresidues/chap\%20

[21] Morales, F.J. (1994) Viral Diseases. In: Lenné, J.M. and Trutmann, P., Eds., Diseases of Tropical Pasture Plants, CAB International, Wallingford, 197-225

[22] Pypers, P., Sanginga, J.M., Kasereka, B., Walangululu, M. and Vanlauwe, B. (2010) Increased Productivity through Integrated Soil Fertility Management in Cassava-Legumes Intercropping System in the Highlands of Sud-Kivu DRC. Field Crops Research, 120, 76-85.

[23] Ndove, T.S., Whitbread, A.M., Clark, R.A. and Pengelly, B.C. (2004) Identifying the Factors that Contribute to the Successful Adoption of Improved Farming Practices in the Smallholder Sector of Limpopo Province, South Africa. In: Whitbread, A.M. and Pengelly, B.C., Eds., Tropical Legumes for Sustainable Farming Systems in Southern Africa and Australia, ACIAR Proceedings No. 115, 146-153. 